\title{
Assessment of the sustainability of multipliers as the core of the region's agroeconomic system
}

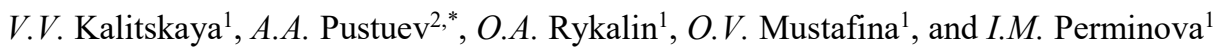 \\ ${ }^{1}$ Ural State Economic University, Ekaterinburg, Russia \\ ${ }^{2}$ Ural State Law University, Ekaterinburg, Russia
}

\begin{abstract}
This article examines the role of multipliers - subsectors of agriculture, as the core of the agroeconomic system of any region, using the example of the Ural Federal Okrug, and also evaluates their sustainability based on materials from 2010-2015. Three basic subsectors are analyzed as multipliers: grain production, dairy farming and poultry farming. As a result of the author's calculations using the appropriate methods, a conclusion was drawn about the dependence of the basic industries on each other, as well as on the market model in a particular territory.
\end{abstract}

\section{Introduction}

In the agroeconomic system, as a set of technologically interconnected industries and types of entrepreneurial activity aimed through market relations to solve the problem of food selfsufficiency with a predominant focus on import substitution, three basic sub-sectors can be distinguished as elements of this system: grain production, dairy farming and poultry farming, that is, which are the basis for solving the above problem. Wherein, as a backbone, as the "core" of the region's agroeconomic system (RAES), one can call its own grain production, without which it is impossible to solve such a problem as the problem of food self-sufficiency in the region.

\section{Results and Discussion}

The backbone side of grain production, in our opinion, is that this sub-industry, being the "core" of the RAES and closely interacting with its other elements, is capable of forming this system under favorable conditions for integration. Moreover, a sufficiently high mechanized basis of grain production provides certain guarantees for achieving sustainable functioning of the entire RAES.

Integration of grain production with the poultry industry can involve other potential applicants of the RAES in the development process, that is, become a kind of multiplier of

\footnotetext{
*Corresponding author: pustuev@mail.ru
} 
its development. As one of the elements, one can name compound feed production, which cannot work without grain, and poultry farming - without compound feed.

Let us analyze the state of sustainability of the functioning of the basic industries of the Ural Federal Okrug in terms of their suitability to act as multipliers of the RAES development.

Let us assess the sustainability of the poultry industry for the main types of poultry products at all levels: federal, district and regional ones presented in Tables 1, 2, 3 .

Table 1. Dynamics of changes in production volumes of the main types of poultry products in the Russian Federation [1, 2]

\begin{tabular}{|c|c|c|}
\hline \multirow{2}{*}{ Years } & \multicolumn{2}{|c|}{ Production volume (Q) } \\
\cline { 2 - 3 } & $\begin{array}{c}\text { poultry meat, } \\
\text { thousand tons }\end{array}$ & eggs, billion pcs. \\
\hline 2005 & 1,388 & 37.8 \\
\hline 2006 & 1,632 & 38.2 \\
\hline 2007 & 1,925 & 38.2 \\
\hline 2008 & 2,217 & 38.1 \\
\hline 2009 & 2,555 & 39.4 \\
\hline 2010 & 2,678 & 40.8 \\
\hline 2011 & 2,897 & 41.1 \\
\hline 2012 & 3,318 & 41.2 \\
\hline 2013 & 3,832 & 41.3 \\
\hline 2014 & 4,088 & 41.3 \\
\hline $\bar{Q}=\sum_{i=1}^{n} Q_{i} / t$ & 2,653 & 39.7 \\
\hline$K_{y}=\bar{Q} / Q_{\max }$ & & \\
\hline
\end{tabular}

Despite the stable increase in the volume of poultry meat production, the stability coefficient for this product is lower than that for eggs, which is caused by the uneven growth of this product. For example, from 2009 to 2010, the increase amounted to 123 thousand tons, and from 2012 to 2013 - 514 thousand tons, which indicates an underestimation of this indicator, especially since a sharp increase in production volumes is not consistent with a decrease in the effective demand of the population and low exports.

Despite the steady growth of these indicators, own resources in the poultry products market are less stable, which can be explained by the variability of demand due to presence of imported products (poultry meat) and imported products from adjacent regions (egg products) on the market, for which prices, as a rule, are lower than for domestic agricultural products.

Table 2. Dynamics of poultry production in the Russian Federation and Ural Federal Okrug with the calculation of the sustainability coefficient $[1,2]$

\begin{tabular}{|c|c|c|c|c|c|c|c|c|c|c|}
\hline \multirow[t]{2}{*}{ Years } & \multicolumn{2}{|l|}{ RF } & \multicolumn{2}{|l|}{ Kurgan } & \multicolumn{2}{|c|}{ Sverdlovsk } & \multicolumn{2}{|c|}{ Chelyabinsk } & \multicolumn{2}{|l|}{ Tyumen } \\
\hline & $\begin{array}{l}\text { meat in } \\
\text { carcass } \\
\text { weight, } \\
\text { thousan } \\
\text { d tons }\end{array}$ & $\begin{array}{l}\text { eggs, } \\
\text { mln } \\
\text { pcs. }\end{array}$ & $\begin{array}{l}\text { meat in } \\
\text { carcass } \\
\text { weight, } \\
\text { thousan } \\
\text { d tons }\end{array}$ & $\begin{array}{l}\text { eggs } \\
\text { mln } \\
\text { pcs. }\end{array}$ & $\begin{array}{l}\text { meat in } \\
\text { carcass } \\
\text { weight, } \\
\text { thousan } \\
\text { d tons }\end{array}$ & $\begin{array}{l}\text { eggs, } \\
\text { mln } \\
\text { pcs. }\end{array}$ & $\begin{array}{l}\text { meat in } \\
\text { carcass } \\
\text { weight, } \\
\text { thousan } \\
\text { d tons }\end{array}$ & $\begin{array}{l}\text { eggs, } \\
\text { mln } \\
\text { pcs. }\end{array}$ & $\begin{array}{l}\text { meat in } \\
\text { carcass } \\
\text { weight, } \\
\text { thousan } \\
\text { d tons }\end{array}$ & $\begin{array}{l}\text { eggs, } \\
\text { mln } \\
\text { pcs. }\end{array}$ \\
\hline 2000 & 1,035 & 34,085 & 7.9 & $\begin{array}{l}167 . \\
5\end{array}$ & 67 & $\begin{array}{l}1,381 . \\
6\end{array}$ & 64 & 945.1 & 18.9 & $\begin{array}{l}1,031 . \\
3\end{array}$ \\
\hline 2001 & 1,098 & 35,242 & 8.2 & $\begin{array}{l}225 . \\
7\end{array}$ & 70 & 1,344 & 67 & 987 & 21.4 & 1,058 \\
\hline 2002 & 1,118 & 36,378 & 9.6 & $\begin{array}{l}215 . \\
5\end{array}$ & 72 & 1,379 & 69 & 1,034 & 22.8 & $\begin{array}{l}1,109 . \\
2\end{array}$ \\
\hline
\end{tabular}


Table 2. Continued

\begin{tabular}{|c|c|c|c|c|c|c|c|c|c|c|}
\hline 2003 & 1,104 & 36,625 & 10.9 & $\begin{array}{l}248 . \\
3\end{array}$ & 75 & 1,395 & 71 & 1,108 & 23.7 & $\begin{array}{l}1,173 . \\
5\end{array}$ \\
\hline 2004 & 1,350 & 35,901 & 10.1 & $\begin{array}{l}233 . \\
3\end{array}$ & 78 & 1,375 & 76 & 1,139 & 24.6 & $\begin{array}{l}1,196 . \\
5\end{array}$ \\
\hline 2005 & 1,388 & 37,140 & 9.7 & $\begin{array}{l}192 . \\
3\end{array}$ & 80 & 1,379 & 88.5 & $\begin{array}{l}1,187 . \\
7\end{array}$ & 26 & $\begin{array}{l}1,255 . \\
8\end{array}$ \\
\hline 2006 & 1,632 & 38,216 & 9.4 & 119 & 83 & 1,312 & 91.4 & 1,213 & 27 & 1,268 \\
\hline 2007 & 1,925 & 38,208 & 10.8 & $\begin{array}{l}120 . \\
1\end{array}$ & 89 & 1,201 & 110.7 & 1,284 & 27.5 & 1,246 \\
\hline 2008 & 2,217 & 38,058 & 10.5 & $\begin{array}{l}120 . \\
9\end{array}$ & 96 & 1,237 & 122.2 & 1,315 & 26.9 & 1,281 \\
\hline 2009 & 2,555 & 39,429 & 10.5 & $\begin{array}{l}126 . \\
3\end{array}$ & 101 & 1,259 & 138.7 & $\begin{array}{l}1,361 . \\
1\end{array}$ & 27.1 & $\begin{array}{l}1,323 . \\
2\end{array}$ \\
\hline 2010 & 2,830 & 40,600 & 12.5 & $\begin{array}{l}119 . \\
5\end{array}$ & 105 & 1,278 & 159.8 & $\begin{array}{l}1,305 . \\
6\end{array}$ & 29 & $\begin{array}{l}1,359 . \\
3\end{array}$ \\
\hline 2011 & $3,204.2$ & 41,113 & 12.7 & $\begin{array}{l}127 . \\
9\end{array}$ & 110 & 1,293 & 173.5 & $\begin{array}{l}1,322 . \\
2\end{array}$ & 31.2 & $\begin{array}{l}1,398 . \\
7\end{array}$ \\
\hline 2012 & $3,624.8$ & 42,033 & 12.7 & 132 & 112 & 1,321 & 196.5 & $\begin{array}{l}1,354 . \\
9\end{array}$ & 33 & $\begin{array}{l}1,414 . \\
9\end{array}$ \\
\hline 2013 & 3,817 & 41,286 & 12.9 & $\begin{array}{l}113 . \\
8\end{array}$ & 114 & $\begin{array}{l}1,387 . \\
9\end{array}$ & 220.3 & $\begin{array}{l}1,403 . \\
9\end{array}$ & 33.2 & $\begin{array}{l}1,425 . \\
9\end{array}$ \\
\hline 2014 & 4,217 & 41,860 & 11.1 & 107 & 106 & $\begin{array}{l}1,387 . \\
5\end{array}$ & 234.3 & 1,477 & 34.5 & $\begin{array}{l}1,445 . \\
1\end{array}$ \\
\hline 2015 & $4,535.5$ & $\begin{array}{l}42,571 . \\
7\end{array}$ & 12.2 & 102 & 108 & $\begin{array}{l}1,442 . \\
9\end{array}$ & 277.5 & 1,498 & 31.9 & $\begin{array}{l}1,458 . \\
3\end{array}$ \\
\hline $\begin{array}{l}\text { On } \\
\text { averag } \\
\text { e }\end{array}$ & $2,345.5$ & $\begin{array}{l}38,673 . \\
2\end{array}$ & 10.73 & $\begin{array}{l}154 . \\
4\end{array}$ & 91.6 & $\begin{array}{l}1,249 . \\
4\end{array}$ & 135 & $\begin{array}{l}1,254 . \\
8\end{array}$ & 27.4 & $\begin{array}{l}1,277 . \\
8\end{array}$ \\
\hline $\mathrm{K}_{\mathrm{u}}$ & 0.517 & 0.908 & 0.83 & $\begin{array}{l}0.62 \\
2 \\
\end{array}$ & 0.81 & 0.866 & 0.486 & 0.83 & 0.794 & 0.87 \\
\hline
\end{tabular}

Although the oligopolistic nature of the poultry market and increase in sales of it to large retail chains are gradually stabilizing not only sales volumes, but also price ratios between domestic poultry organizations.

The most unstable nature of the dynamics of growth of poultry resources in the food market was noted in 2010: in the second quarter, in comparison with the first one, the increase amounted to 29 thousand tons, in the third one, in comparison with the second one, - 59 thousand tons and in the fourth one -383 thousand tons (on average 157 thousand tons).

Table 3. Dynamics of quarterly changes in production-export-import elements in the poultry market in 2013-2014 [1,2]

\begin{tabular}{|c|c|c|c|c|c|c|}
\hline \multirow{2}{*}{$\begin{array}{c}\text { Years and } \\
\text { periods }\end{array}$} & $\begin{array}{c}\text { production, } \\
\text { thousand } \\
\text { tons }\end{array}$ & $\begin{array}{c}\text { import, } \\
\text { thousand } \\
\text { tons }\end{array}$ & $\begin{array}{c}\text { export, } \\
\text { thousand } \\
\text { tons }\end{array}$ & $\begin{array}{c}\text { Eggs } \\
\text { production, } \\
\text { billion pcs. }\end{array}$ & $\begin{array}{c}\text { import, bln } \\
\text { pcs. }\end{array}$ & $\begin{array}{c}\text { export, } \\
\text { billion } \\
\text { pcs. }\end{array}$ \\
\hline $\begin{array}{c}2013 \\
\text { Total: }\end{array}$ & $3,831.6$ & 550.2 & 53.8 & $41,286.0$ & $8,292.0$ & 290.0 \\
\hline $\begin{array}{c}\text { incl. } \\
\text { I quarter }\end{array}$ & 903.7 & 109.0 & 10.6 & $9,795.4$ & 163.7 & 50.3 \\
\hline II quarter & 918.8 & 131.6 & 13.5 & $11,217.2$ & 388.9 & 72.4 \\
\hline III quarter & 934.7 & 153.2 & 13.9 & $10,607.4$ & 223.6 & 84.0 \\
\hline IV quarter & $1,074.4$ & 156.4 & 15.8 & $9,666.0$ & 216.7 & 83.3 \\
\hline K & 0.89 & 0.88 & 0.85 & 0.92 & 0.63 & 0.86 \\
\hline $\begin{array}{c}\text { 2014 } \\
\text { Total: }\end{array}$ & $4,088.0$ & 467.2 & 61.8 & $41,263.3$ & 915.2 & 185.0 \\
\hline $\begin{array}{c}\text { incl. } \\
\text { I quarter }\end{array}$ & 936.1 & 88.3 & 15.6 & $9,547.6$ & 242.2 & 44.2 \\
\hline II quarter & 980.5 & 137.1 & 15.9 & $10,900.9$ & 228.9 & 52.8 \\
\hline III quarter & 998.8 & 107.6 & 15.0 & $10,933.8$ & 219.1 & 56.5
\end{tabular}


Table 3. Continued

\begin{tabular}{|c|c|c|c|c|c|c|}
\hline IV quarter & $1,172.6$ & 134.2 & 16.3 & $9,881.0$ & 225.0 & 31.5 \\
\hline $\mathrm{K}_{\mathrm{u}}$ & 0.87 & 0.85 & 0.96 & 0.94 & 0.95 & 0.82 \\
\hline Average $\mathrm{K}_{\mathrm{u}}$ & 0.88 & 0.865 & 0.905 & 0.93 & 0.79 & 0.84 \\
\hline
\end{tabular}

The average quarterly increase in imports in 2009 amounted to 55.6 thousand tons, in 2010 - 86 thousand tons, which indicates a constant increase in this indicator and an increase in selling prices.

Let us analyze the nature of the change in these prices for the period 2010-2015 using the example of the Ural Federal Okrug (UFO). It is very difficult to solve this problem on average in the country, since each region and even a constituent entity of the Russian Federation has its own price level, which depends on such indicators as the degree of competition in the poultry market in terms of the share of each poultry organization in it, the effective demand of the population, and climatic conditions.

The data in Table 4 indicate a stable growth in prices for poultry meat and a somewhat uneven change in prices for egg products.

Table 4. Dynamics of change in selling prices for poultry products in the Ural Federal Okrug for 2010-2015

\begin{tabular}{|c|c|c|c|c|c|c|c|c|c|}
\hline Products & 2010 & 2011 & 2012 & 2013 & 2014 & 2015 & $\begin{array}{c}\text { On average } \\
\text { for 2010- } \\
2015\end{array}$ & $\mathrm{~K}_{\mathrm{u}}$ & $\begin{array}{c}2015 \text { to } \\
2010, \%\end{array}$ \\
\hline Poultry meat & 85.8 & 89.2 & 92.0 & 91.2 & 90.6 & 108.7 & 92.9 & 0.854 & 126.7 \\
\hline eggs & 30.4 & 27.6 & 33.8 & 33.1 & 40.1 & 48.0 & 33.5 & 0.74 & 157.9 \\
\hline
\end{tabular}

An increase in the cost of material and technical resources has a negative impact on the economy of poultry organizations. Considering the high costs of compound feed and a decrease in stability in income generation, some of these agricultural structures are trying to compensate for the risk of managing their core activities by developing diversification activities, producing other types of agricultural products, animal husbandry and grain production.

Wherein, grain can be used for the production of compound feed, which is more profitable in the context of integration with compound feed factories.

The next basic industry (sub-industry) is grain production, which is unstable due to unstable yield, which directly depends on natural and climatic conditions (Table 20). Some regions suffer from drought, others from excessive moisture, and often from aridity during the growing season of plants and moisture during harvesting.

According to average statistical data and the results of study by a number of scientists, especially the "pre-market" period, biological, technological and "man-made" grain losses amount to 15-20 million tons $[3,4,5,6]$.

For example, as a result of the harvesting period prolonged in 2015 due to rainy weather, about $30 \%$ of grain crops remained unharvested in the Sverdlovsk region, some of which remained under the snow [7, 8, 9].

The high seasonal load on the harvesting area on the grain harvester and other reasons do not allow completing the harvesting process within the time recommended by science and practice of 10-12 days. For each day following the above-mentioned period, losses increase almost exponentially.

In this regard, there is a significant difference even between the biological yield of grain crops and the "bunker" weight of threshed bread [3, 10, 11, 12, 13].

The next system-forming element of the RAES is dairy farming, which in terms of the production of milk and dairy products in the region amounts to an average of $6.4 \%$ of the all-Russian level. The dynamics of milk production in the region and the country is quite stable, $K_{u}=0.912$ (in the Russian Federation - 0.95), in the context of the regions of the 
Ural Federal Okrug $\mathrm{K}_{\mathrm{u}}$ was: 0.784 - Kurgan region; 0.934 - Sverdlovsk region; 0.879 Chelyabinsk region; 0.91 - Tyumen region.

The results of calculating $K_{u}$ for the backbone subsectors are given in Table 5.

Table 5. The values of the coefficient of sustainability of production of products of backbone subsectors in farms of all categories of subjects of the Ural Federal Okrug ${ }^{1)}$

\begin{tabular}{|l|l|c|c|c|c|}
\hline \multirow{2}{*}{ Product type } & $\begin{array}{c}\text { Objects for calculating } \\
K_{\mathrm{u}}\end{array}$ & \multicolumn{4}{c|}{ The value of $\mathrm{K}_{\mathrm{u}}$ by UFO subjects } \\
\cline { 3 - 6 } & & $\begin{array}{c}\text { Kurgan } \\
\text { region }\end{array}$ & $\begin{array}{c}\text { Sverdlovs } \\
\text { k Region }\end{array}$ & $\begin{array}{c}\text { Chelyabin } \\
\text { sk region }\end{array}$ & $\begin{array}{c}\text { Tyumen } \\
\text { Region }\end{array}$ \\
\hline \multirow{3}{*}{ Grain } & Sown area & 0.89 & 0.83 & 0.897 & 0.935 \\
\cline { 2 - 6 } & Yield & 0.63 & 0.75 & 0.683 & 0.76 \\
\cline { 2 - 6 } & Volume of production & 0.545 & 0.812 & 0.66 & 0.701 \\
\hline Milk & Volume of production & 0.784 & 0.934 & 0.879 & 0.91 \\
\hline Poultry meat & Volume of production & 0.83 & 0.81 & 0.486 & 0.794 \\
\hline Eggs & Volume of production & 0.622 & 0.866 & 0.83 & 0.87 \\
\hline
\end{tabular}

It shall be noted that the above presented systemic industries (poultry farming, grain production and dairy farming) are directly related to feed production, therefore, this industry can also be connected to the systemic ones. However, the instability of economic relations in the system of "grain-feed" is a limiting factor in the connection of this industry to the multiplier of the development of other industries, especially to grain production. The instability of price ratios between grain and compound feed producers is forcing agricultural organizations to produce compound feed on their own resources. This tendency is typical, for example, for the Sverdlovsk region, where its feed mills use fodder grain from farms in the Orenburg and Kurgan regions as raw materials. The main reason is the disagreement of Sverdlovsk grain producers to supply grain to feed mills at a reduced price.

Presence of price disagreements can be explained by different market models in which "grain growers" and compound feed producers are located. The former operate in a model close to perfect competition, and the latter - to an oligopoly.

\section{Conclusion}

However, not all measures for development of the poultry industry in the Russian Federation outlined in the program are being implemented. So, for example, in section 4.2. The (Market Regulation) program outlined the following measures:

1. To develop national standards for poultry products, regulatory legal acts and methodological documents on price regulation.

2. Improvement of legal regulation, namely, the definition of product quality criteria and the level of trade margins.

3. To create the infrastructure of specialized wholesale markets for poultry products with the allocation of land plots on priority terms in order to develop trading activities, regulate supply and demand, reduce the cost of selling products, increase the role of exhibitions and fairs.

4. To consider the issue of including the industry in the system of purchases of eggs, meat and meat products from poultry meat for federal and regional state needs.

5. To expand the network of branded stores of poultry products, increase advertising support.

It can be noted that clauses 3 and 5 have not yet been fulfilled, since their own wholesale and retail system in the poultry market has not been created in the interests of agricultural producers. In fact, it is captured by large private retail chains, where it mainly sells its products to poultry farms.

In conclusion, we note that in modern crisis conditions, justification of the stability of economic indicators can be carried out only within certain (limited) limits, since it is 
practically impossible to consider all risk situations of a bifurcation nature. Difficulties in the calculation process also arise due to the need to consider the social side of sustainability of agroeconomic - territorial systems, the effective management of the development of which depends on social and motivational factors.

\section{References}

1. On the situation on the poultry market in 2005-2014 (2015)

2. Information bulletins of the Rospitsesoyuz, 80-88

3. Regions of the UFO: the results of socio-economic development (2010)

4. V. Veklenko, E. Zolotareva, APK: economics, management, 10, 49-56 (2002)

5. A.V. Golubev, A.A. Golubeva, Economy of agricultural and processing enterprises, 3, 12-14 (2014)

6. P.M. Ivanov, Economics and Mathematical Methods, 42, 51-59 (2006)

7. A.N. Kashtanov, Sustainability of farming: ways to improvement, 230 (1983)

8. Agriculture, hunting and hunting farms, forestry in Russia (official publication), Stat. collection: Federal State Statistics Service (2015)

9. V.K. Chashin, A.L. Pustuev, Monitoring in the food security system, 439 (2004)

10. A.A. Chernyaev, D.V. Serdobintsev, Economy of agricultural and processing enterprises, 6, 27-31 (2013)

11. M.M. Yuzbashev, O.V. Popova, Bulletin of statistics, 9 (1980)

12. E.V. Stovba, Economics and Management, 5, 52-55 (2003)

13. A.N. Semin, Methodological support of scientific research of economic problems of development of the agro-industrial complex of Russia, 318-331 (2016) 